\title{
Waterbird population estimates for a key staging site in Kazakhstan: a contribution to wetland conservation on the Central Asian flyway
}

\author{
HOLGER SCHIELZETH, GÖTZ EICHHORN, THOMAS HEINICKE, JOHANNES \\ KAMP, MAXIM A. KOSHKIN, ALEXEJ V. KOSHKIN and LARS LACHMANN
}

\begin{abstract}
Summary
Realistic population size estimates for waterbirds are crucial for the application of wetland conservation strategies, since the identification of internationally important wetlands is based on local numbers relative to the population size of the respective species. Central Asia is a poorly surveyed region that is situated at the intersection of migration routes that lead waterbirds from Western Siberia to the south-west (South-West Asia, East Africa) and to the south-east (South Asia, India). We calculated waterbird population estimates for the Tengiz-Korgalzhyn region, a large wetland complex in the steppe zone of Central Kazakhstan, based on waterbird surveys conducted between 1999 and 2004. For 20 of 43 species analysed the region supported more than $5 \%$ of the relevant flyway populations. Five species occurred with more than $40 \%$ of the flyway totals, including the Endangered White-headed Duck Oxyura leucocephala and the Vulnerable Dalmatian Pelican Pelecanus crispus. Peak numbers were recorded in summer and autumn and for most species numbers were more than an order of magnitude lower on spring migration compared with autumn migration. We identified 72 individual sites that held more than 20,000 waterbirds or more than $1 \%$ of a particular flyway population at least once. These sites are likely to constitute priorities for conservation. The general conservation status of the region is favourable, since many of the important sites are located within a strict nature reserve. However, outside the reserve hunting, fishing and powerline casualties represent conservation issues that should be monitored more carefully in the future.
\end{abstract}

\section{Introduction}

Attempts to establish a network of protected wetlands to support waterbird populations have focused on regionalized flyway and/or wintering populations (Scott and Rose 1996, Beintema and van Vessem 1999, Wetlands International 2006). One of the most important tools for the identification of internationally important wetlands is provided by the criteria of the Ramsar Convention (Davis 1994, Frazier 1999). They state that an internationally important wetland must support more than 20,000 individuals of waterbirds or regularly host more than $1 \%$ of the relevant flyway population of a particular species. The application of the latter criterion relies on realistic estimates for the flyway population size (Hagemeijer and Blair 1997, Bibby et al. 1998, Wetlands International 2006) while sufficient data from all potentially important wetlands are needed to establish a network of wetlands that supports migrating waterbirds. Within the vast breeding ranges of northern Asia surveys are extremely difficult to conduct. Therefore, flyway population estimates are mainly based on counts from wintering grounds (Rose 1995, Delany 
et al. 1999, Gilissen et al. 2002, Wetlands International 2006). Supporting data from migratory staging sites are very limited but are of immense value, both in terms of providing additional information on abundance and distribution, and to ensure important sites are identified and protected.

Central Asia is a vast and poorly investigated region that is situated at the intersection of waterbird populations migrating from Western Siberia to the south-west (Caspian region, South-West Asia, East Africa, Europe) and populations migrating to the south-east (South Asia, Indian Subcontinent) (Scott and Rose 1996, Sema 2002, Veen et al. 2005, Solokha 2006; Figure 1). Most of Central Asia is covered by steppe, semi-desert and desert, providing only very localized resting habitat for migrating waterbirds. The Tengiz-Korgalzhyn region (c. $49 \cdot 5-51^{\circ} \mathrm{N} 68-71^{\circ} \mathrm{E}$ ) comprises one of the most important wetland complexes in Central Asia. Despite its well-known importance for migratory birds (e.g. Krivitskij et al. 1985, Andrusenko 2002, Koshkin 2002, 2003, Koshkin and Koshkina 2003), few attempts have been made to estimate population sizes of waterbirds (except for papers focusing on single species: Koshkina 1999, Eichhorn and Khrokov 2002, Schielzeth et al. 2003, Andrusenko 2004b). However, the global importance of this wetland complex presents a need for the collection and interpretation of abundance and distribution data to inform conservation decisions at a flyway scale and to improve our knowledge about the use of this area by migratory waterbirds.

Here we present population estimates for the Tengiz-Korgalzhyn wetland complex based on intensive surveys conducted between 1999 and 2004, and compare them with the relevant flyway population estimates. We analysed data on 43 species of the orders Gaviiformes,

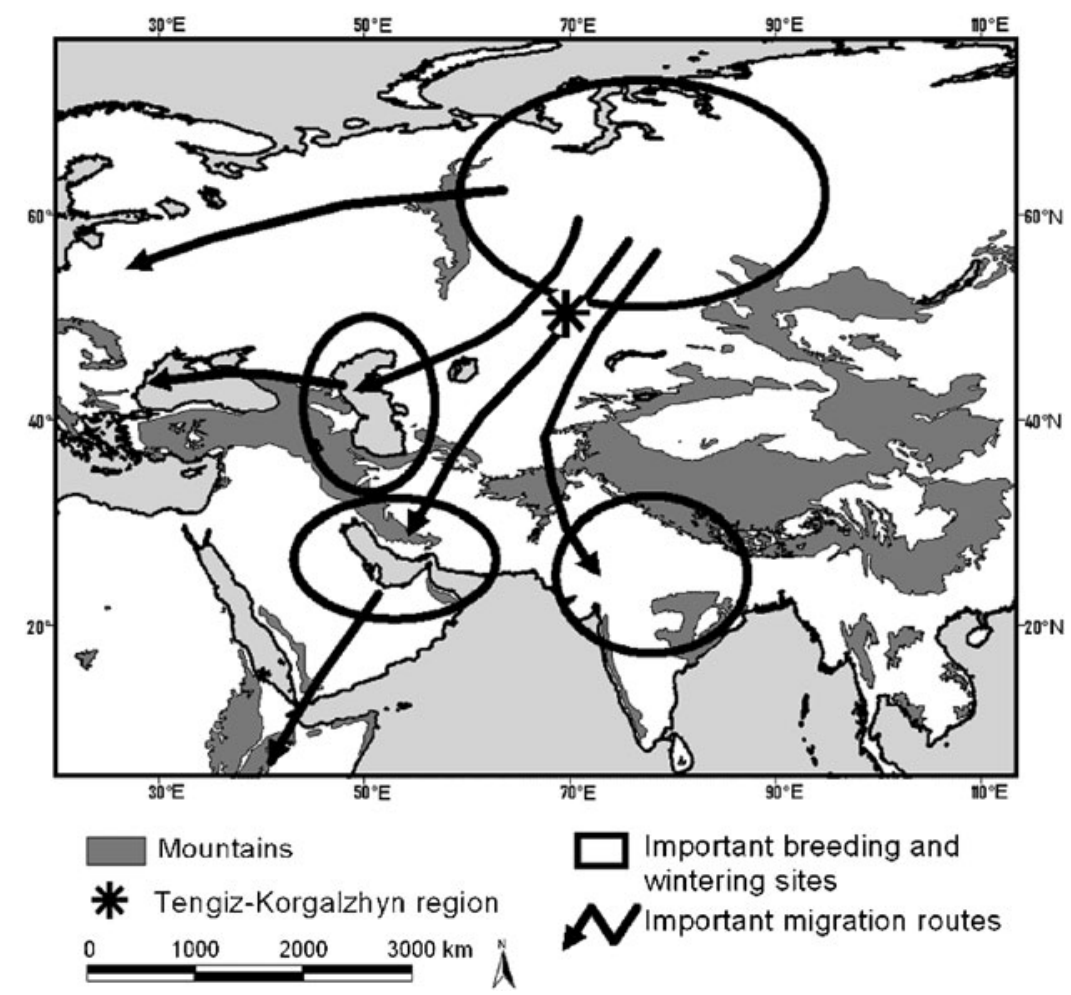

Figure 1. Main breeding area, wintering grounds and major migration routes of waterbirds in western Asia (based on Scott and Rose 1996, Wetlands International 2006). 
Podicipediformes, Pelecaniformes, Ciconiiformes, Anseriformes and Gruiformes. Particularly secretive species such as bitterns and crakes have been excluded, because they were not adequately covered in our surveys. Our population estimates refer to maximum staging numbers that usually occur at the peak of the migration season. The total number of individuals stopping over in the region is undoubtedly much higher due to migratory turnover of individuals.

\section{Study area}

The survey area extends from the settlements of Sochinskoje in the north-west to Malinovka in the east and Barshyn in the south $\left(49^{\circ} 40^{\prime}-51^{\circ} 10^{\prime} \mathrm{N} 68^{\circ} 20^{\prime}-71^{\circ} \mathrm{Oo}\right.$ ' E, c. $180 \mathrm{~km} \times 150 \mathrm{~km}$; Figure 2). With an area of $2,370 \mathrm{~km}^{2}$ the Korgalzhynskij zapovednik forms the core of the region. A zapovednik is a strict nature reserve (IUCN category 1a) that allows only limited human activities (mainly research and limited tourism). The Korgalzhynskij zapovednik was designated in 1968 and slightly extended in 1997/8. It was declared a Ramsar site by the Soviet government in 1976, and this status has recently been confirmed by the Republic of Kazakhstan (BirdLife International 2007). The zapovednik encompasses the highly saline lakes Bolshoj and Malij Tengiz as well as the freshwater Lake Korgalzhyn. It also includes the extensive delta regions of the main tributaries Nura and Kulanotpes.

The area north and east of the zapovednik has been intensively cultivated, starting with the Soviet Virgin Land Campaign in the 1950 os (Dieterich 2000). The arable fields are dominated by crops of wheat, which provide good feeding opportunities for geese and ducks in autumn. However, due to economic changes after the collapse of the Soviet Union, cereal cultivation is no longer subsidised. In consequence, huge areas have fallen fallow and are currently reverting to steppe (de Beurs and Henebry 2004). This also concerns our study area, where approximately $80 \%$ of former agricultural land is now abandoned (unpubl. data). Most of the human population is concentrated in the cultivated area, which leads to higher levels of disturbance, e.g. by work in the fields, fishing and hunting activities. There are plans to declare a large part of the region an Important Bird Area, but currently only Lake Isej (a lake within the zapovednik) has been officially recognized (Sklyarenko 2006).

Due to the continental climate in Central Kazakhstan, the Tengiz-Korgalzhyn region is of no importance for wintering waterbirds. Cold spells cause the lakes to freeze often as early as October and ice cover may persist until mid-April. Waterbirds leave the region rapidly when temperatures plummet in October.

\section{Methods}

\section{Survey methods}

Surveys were carried out between 1999 and 2004 using the villages of Karazhar $\left(50^{\circ} 28^{\prime} \mathrm{N}\right.$ $\left.69^{\circ} 33^{\prime} \mathrm{E}\right)$ and Korgalzhyn $\left(50^{\circ} 35^{\prime} \mathrm{N} 70^{\circ} \mathrm{OI}^{\prime} \mathrm{E}\right)$ as field bases. Usually one car with one to three fieldworkers was in use ( $75 \%$ of all counts were done by single observers). In total, 16 different observers contributed to the counts, but the majority of data $(97 \%)$ were collected by six observers (yearly numbers of observers who contributed for a period of at least 1 month were as follows: 1999, 4; 2000, 3; 2001, 3; 2002, 2; 2003, 3; 2004, 3). The surveys were designed to maximize the number of sites visited, with successive counts at the same site at least 1o days apart. This means that there were only a few occasions on which a particular site was sampled twice in a given third of a month (except for a few sites in the vicinity of field bases). In cases of multiple counts from one third of a month we used the highest count in calculations of population sizes.

In total, 177 sites were visited at least once ( $86 \pm 32$ per year, mean $\pm S D$; range 44-110). This means that survey effort varied widely between years and in none of the years could all 
sites be surveyed (Figures 2 and 3). For the central part of the study area (c. $50 \mathrm{~km}$ around field bases) gaps in site coverage refer mainly to sites of lesser importance, but some important lakes in the north, east and south of the region could not be surveyed adequately (Figure 2). Air surveys of Lake Korgalzhyn and the eastern Bolshoj Tengiz were conducted on three occasions (31 May 2000, 22 August 2002 and 27 August 2004).

The duration of stops at single sites depended largely on the number of birds present and ranged from 10 minutes to a few hours. Smaller sites were counted from single spots, whereas larger lakes required observations from several viewpoints. All counts were conducted using spotting scopes with at least $30 \times$ magnification as well as binoculars. Waterbirds were counted individually or in blocks of 10,100 or, very occasionally, 1,000 individuals. Counting errors increase with increasing numbers (Rappoldt et al. 1985), but there is a general tendency to underestimate larger bird flocks (Underhill and Prŷs-Jones 1994, Frederick et al. 2003). Given the large numbers of birds and large observation distances it is likely that scarcer as well as less detectable species were underestimated, since they are easily overlooked among common ones.

\section{Calculation of local population sizes}

The aim of this study was to estimate peak staging numbers of waterbirds in the TengizKorgalzhyn region. The true number of individuals that had visited the region was certainly higher, since our estimates do not consider turnover of individuals. Turnover usually contributes significantly to the actual number of individuals (Pradel et al. 1997, Frederiksen et al. 2001, Schaub et al. 2001).

Population estimates were derived from count data of individual sites. These sites varied greatly in size as well as in their importance for waterbirds. All calculations were carried out on the basis of thirds of a month (day $1-10,11-20$ and $21-30 / 31$ of each month), which gives sufficient temporal resolution while excluding significant changes in numbers caused by local movements or immigration and emigration to and from the study area. We analysed the data separately for the months March to mid-June (referred to as 'spring') and end June to November ('autumn'). We chose this cut-off point because many species of waterbirds start moult migration as early as June (Veen et al. 2005).

To estimate the population size of a particular species we calculated

$$
N_{j k}=\sum_{i=1}^{n} c_{i j k}
$$

for every third of a month in every year, where $c_{i j k}$ is the count for site $i$ in year $j$ and third of a month $k . N_{j k}$ represents the number of individuals of a particular species counted in a given third of a month in a given year, cumulated from all sites for which data were available. Assuming only minor changes in the distribution of birds within the third of a month being considered, this represents a minimum number of birds present. The maximum of this estimate, $\max \left(N_{j k}\right)$, is the peak number of individuals of a given species recorded at least once during our study period. We refer to $\max \left(N_{j k}\right)$ as 'estimate I $\left(E s t_{1}\right)^{\prime}$ for the local population of a particular species. Because of the large size of the region (see Survey Methods above), this figure never includes all relevant sites.

Furthermore, we calculated

$$
N_{k}=\sum_{i=1}^{n} a_{i k}
$$

for every species and every third of a month, where $a_{i k}$ is the number of birds at site $i$ in third of a month $k$ averaged over all years for which data were available. $N_{k}$ represents the number of individuals of a particular species counted in a given third of a month independent of year, cumulated from 'typical' (i.e. average) site counts. The highest value of $N_{k}$ captures the peak of 

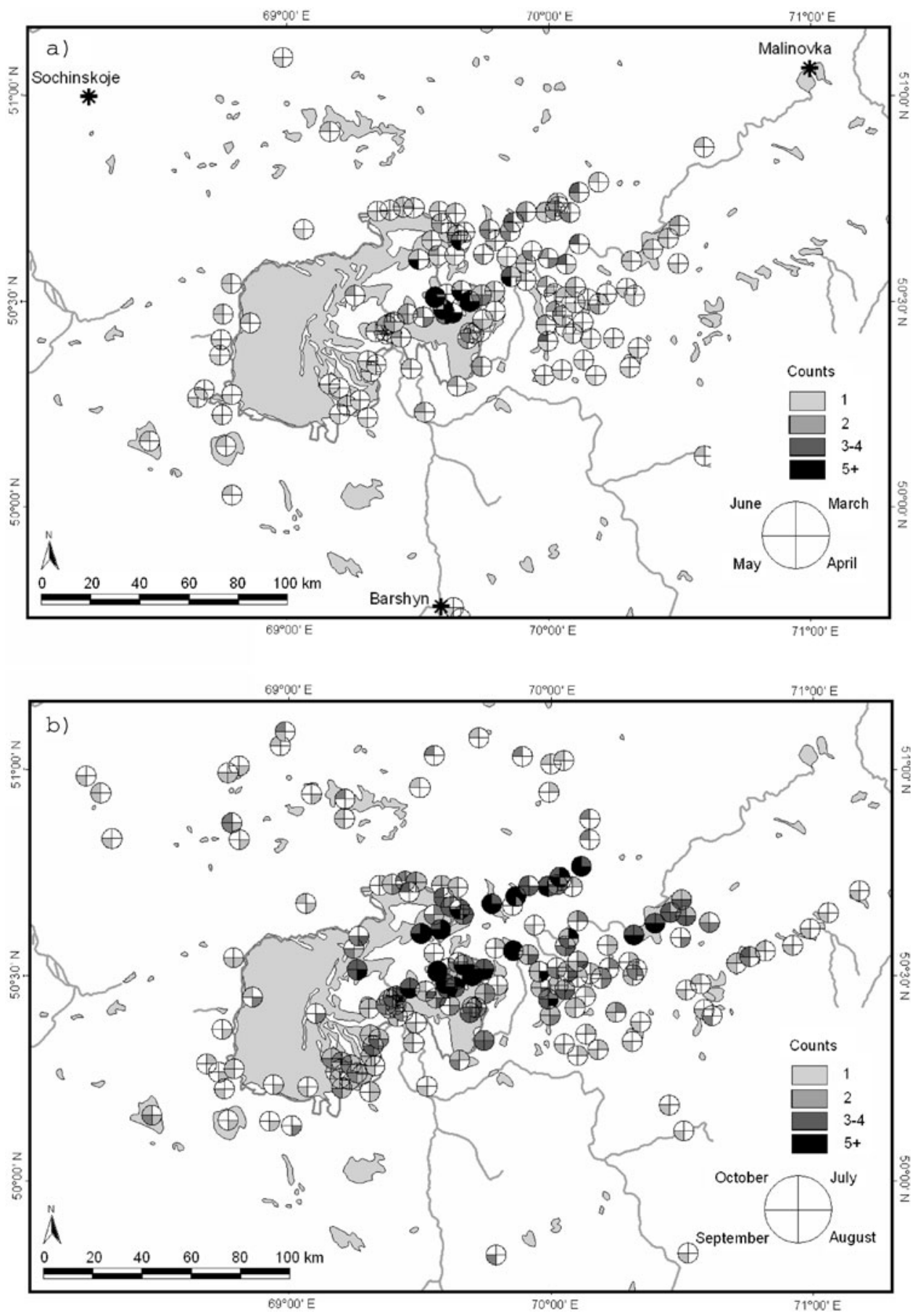

Figure 2. Spatial-temporal distribution of survey activity in the Tengiz-Korgalzhyn region in (a) March to June and (b) July to October. The number of counts per third of a month and site is shown for the years 1999-2004 combined. 


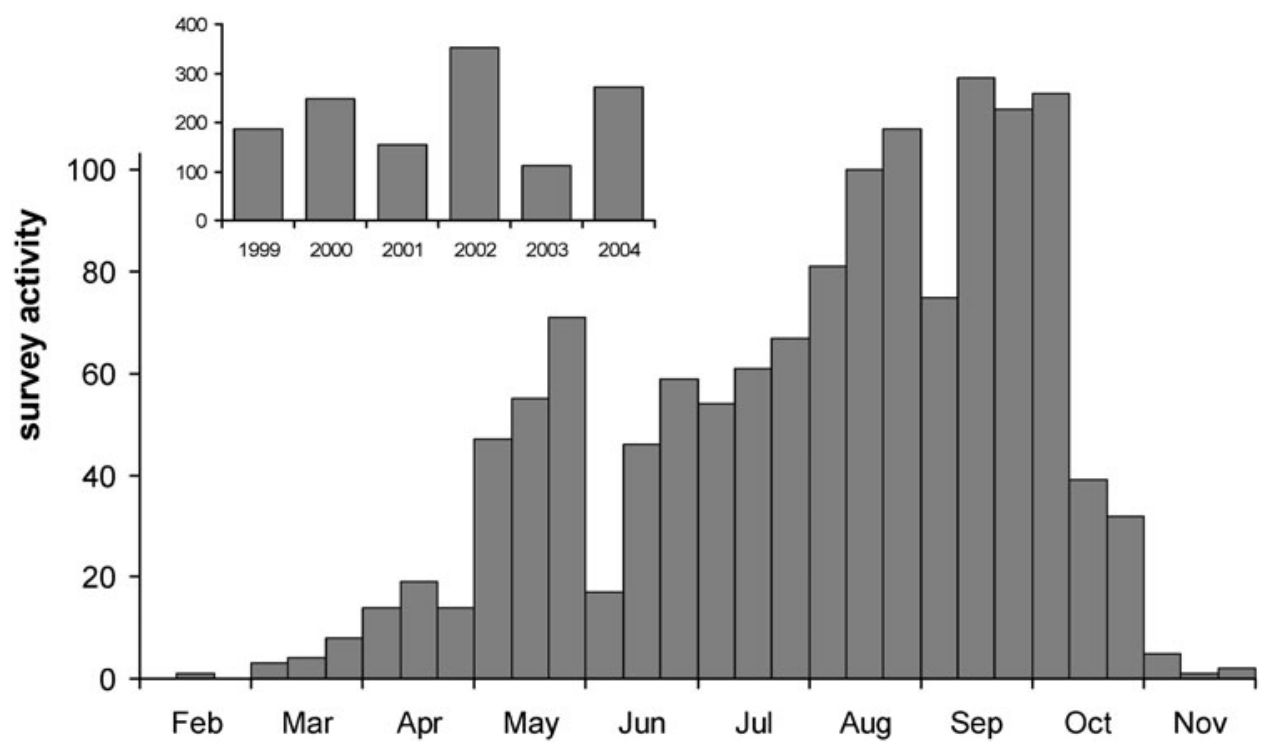

Figure 3. Survey intensity in the Tengiz-Korgalzhyn region measured as the number of counts per third of a month (main figure) and year (upper left corner).

occurrence, and we refer to the maximum, $\max \left(N_{k}\right)$, as 'estimate $2\left(E s t_{2}\right)^{\prime}$ for the local population of a particular species.

Estimate $2\left(E s t_{2}\right)$ tends to be higher than estimate $I_{(}\left(E s t_{1}\right)$, since the former contains better site coverage. However, for species occurring in numbers that fluctuate strongly between years, Est $t_{2}$ might be lower than $E_{s t}$. To be conservative in our estimates, we present a final 'total estimate' in ranges of rounded figures between the two estimates, no matter which one yielded higher figures. We rounded numbers below 100 to the nearest 5 , below 1 , ooo to the nearest 10 , below 10,000 to the nearest 100 and above 10,000 to the nearest 1,000. Estimates below 5 but above zero were set to $0-5$. Relevant for the rounding accuracy was the lower estimate.

Furthermore we present the current breeding status for all species in the area. We did not conduct any dedicated breeding surveys, so the status information is categorized in rough classes aiming mainly to give an overview of the waterbird breeding fauna. It is not meant to anticipate detailed breeding surveys.

\section{Comparison with flyway population estimates}

To evaluate the importance of the Tengiz-Korgalzhyn region on a flyway scale, we compared our estimates with the flyway population estimates from Wetlands International (2006). Since waterbird populations from Central Asia might migrate to the south-west as well as to the south-east (Veen et al. 2005; Figure 1), we often had to combine the estimates of two or more flyway populations. For these cases, the Tengiz-Korgalzhyn estimates were compared with the summed total of all relevant populations. We used mid-range values for both the TengizKorgalzhyn and the flyway population estimates in all comparisons.

Since local conservation efforts have to act on smaller scales than the Tengiz-Korgalzhyn region as a whole, we identified individual sites within our study area that held important numbers of waterbirds. For this we used the $1 \%$ criterion for flyway populations of particular species and the 20,000 waterbirds criterion according to the Ramsar convention (Frazier 1999, Wetlands International 2006). Individual sites that reached one of the thresholds at least once 
during the study period were classified as important. These sites are likely to constitute priority sites for conservation in the Tengiz-Korgalzhyn region.

\section{Results}

Combined estimates of all species analysed here numbered 41,000-51,000 in spring and 1.3-1.7 million individuals in summer-autumn (Tables 1 and 2). For as many as 33 of the 43 species the wetland complex supports more than $1 \%$ of the total flyway population (Table 3 ). Twenty species occurred in numbers representing more than $5 \%$ of the estimated flyway populations, eight of which exceed 20\% and five of which (including the threatened Dalmatian Pelican Pelecanus crispus and White-headed Duck Oxyura leucocephala) exceeded 40\%. Highest numbers occurred in summer and autumn (Figure 4), while for most species numbers in spring were more than an order of magnitude lower than during autumn migration. Moulting adults of several species (e.g. Black-necked Grebe Podiceps nigricollis, Mute Swan Cygnus olor, Ruddy Shelduck Tadorna ferruginea, Common Shelduck Tadorna tadorna, Red-crested Pochard Netta rufina, Common Pochard Aythya ferina, Common Goldeneye Bucephala clangula, Eurasian Coot Fulica atra, Demoiselle Crane Anthropoides virgo) gathered in large numbers in summer. Many species, however, showed distinct peaks in September/October (Figure 4).

A total of 72 individual sites held more than $1 \%$ of the relevant flyway population of a particular species or more than 20,000 waterbirds at least once during the study period (Figure 5, see Appendix in Supplementary materials). Most of these sites hosted significant numbers in more than one year, but for 34 of them ( 15 of which were visited in one year only) more data are needed to determine whether significant numbers occur regularly (see Appendix in Supplementary materials). The zapovednik comprises 30 of the individual sites considered as important. Outside the protected area, the freshwater lakes east and west of Korgalzhyn village especially were of high importance to waterbirds (Figure 5).

\section{Discussion}

The results of our surveys across the Tengiz-Korgalzhyn region clearly demonstrate the region's outstanding importance for migrating and moulting waterbirds. For moulting waterbirds the region appears to be of similar importance the Volga delta in Russia (Viksne 1989, Bianki and Dobrynina 1997, Fokin et al. 2000, Andrusenko 2004a). Many species (including threatened ones) occurred in numbers comprising large proportions of the total flyway or even global population. For many species, however, it is currently unclear whether, and to what extent, individuals originate from different flyway populations. Sound information on the geographical origin of migrants passing through our study area can be obtained only by individual marking and tracking methods. If it is possible to assign the Tengiz-Korgalzhyn birds more clearly to certain flyway populations, the relative importance of the Tengiz-Korgalzhyn region on a flyway scale will increase, since we often had to combine two or more flyway populations in our comparisons. Further work in this direction is needed to clarify the situation. Nevertheless, the Tengiz-Korgalzhyn region must already be considered a key site for waterbird conservation at a global level.

Numbers in summer and autumn were much higher than during spring migration. This was unlikely to be caused by incomplete spring surveys, since many species of shorebirds were equally numerous in Spring and Autumn or even more abundant in Spring (unpubl. data). Generally, lower spring numbers could arise from (a) winter mortality, (b) overall faster spring migration with shorter staging durations or (c) different migration routes. Perhaps the major reason for the pronounced difference between spring and autumn numbers is the particular climatic situation in Central Asia. During autumn the Tengiz-Korgalzhyn region is the last wetland before migrating waterbirds cross the Betpak-dala semi-desert (c. 500-60o km), and the 
Table 1 . Estimates of waterbird numbers in the Tengiz-Korgalzhyn region during spring (March to midJune). For details on calculations see Calculation of Local Population Sizes.

\begin{tabular}{|c|c|c|c|c|}
\hline Species & & $\begin{array}{l}\text { Est. I } \\
\max \left(N_{j k}\right)\end{array}$ & $\begin{array}{l}\text { Est. } 2 \\
\max \left(N_{k}\right)\end{array}$ & $\begin{array}{l}\text { Total } \\
\text { estimate }\end{array}$ \\
\hline Black-throated Diver & Gavia arctica & 5 & 5 & 5 \\
\hline Red-necked Grebe & Podiceps grisegena & 627 & 785 & $630-790$ \\
\hline Great Crested Grebe & Podiceps cristatus & 983 & 698 & $700-980$ \\
\hline Slavonian Grebe & Podiceps auritus & 47 & 88 & $45-90$ \\
\hline Black-necked Grebe & Podiceps nigricollis & 698 & 605 & $610-700$ \\
\hline Dalmatian Pelican & Pelecanus crispus & 570 & 598 & $570-600$ \\
\hline Great Cormorant & Phalacrocorax carbo & 4,850 & 4,978 & $4,900-5,000$ \\
\hline Grey Heron & Ardea cinerea & 48 & 47 & $45-50$ \\
\hline Great White Egret & Ardea alba & 59 & 61 & 60 \\
\hline Eurasian Spoonbill & Platalea leucorodia & 1 & 1 & $0-5$ \\
\hline Greater Flamingo & Phoenicopterus ruber & 6,729 & 10,078 & $6,700-10,100$ \\
\hline Mute Swan & Cygnus olor & 1,111 & 1,197 & $1,100-1,200$ \\
\hline Whooper Swan & Cygnus cygnus & 816 & 828 & $820-830$ \\
\hline Bewick's Swan & Cygnus columbianus & o & o & $\mathrm{O}$ \\
\hline Bean Goose & Anser fabalis & 1 & 1 & $0-5$ \\
\hline Greater White-fronted Goose & Anser albifrons & 319 & 319 & 320 \\
\hline Lesser White-fronted Goose & Anser erythropus & 2 & 2 & $\mathrm{o}-5$ \\
\hline Greylag Goose & Anser anser & 1,320 & 1,110 & $1,100-1,300$ \\
\hline Red-breasted Goose & Branta ruficollis & o & o & $\mathrm{O}$ \\
\hline Ruddy Shelduck & Tadorna ferruginea & 352 & 352 & 350 \\
\hline Common Shelduck & Tadorna tadorna & 654 & 869 & $650-870$ \\
\hline Eurasian Wigeon & Anas penelope & 870 & 930 & $870-930$ \\
\hline Gadwall & Anas strepera & 302 & 722 & $300-720$ \\
\hline Common Teal & Anas crecca & 1,050 & 1,050 & 1,100 \\
\hline Mallard & Anas platyrhynchos & 1,930 & 2,080 & $1,900-2,100$ \\
\hline Northern Pintail & Anas acuta & 1,300 & 1,360 & $1,300-1,400$ \\
\hline Garganey & Anas querquedula & 203 & 195 & 200 \\
\hline Northern Shoveler & Anas clypeata & 406 & 451 & $410-450$ \\
\hline Red-crested Pochard & Netta rufina & 1,782 & 2,417 & $1,800-2,400$ \\
\hline Common Pochard & Aythya ferina & 10,520 & 14,848 & $11,000-15,000$ \\
\hline Ferruginous Duck & Aythya nyroca & 7 & 8 & $5-10$ \\
\hline Tufted Duck & Aythya fuligula & 603 & 689 & $600-690$ \\
\hline Greater Scaup & Aythya marila & o & o & o \\
\hline Long-tailed Duck & Clangula hyemalis & 3 & 3 & $0-5$ \\
\hline Velvet Scoter & Melanitta fusca & $\mathrm{o}$ & o & o \\
\hline Common Goldeneye & Bucephala clangula & 301 & 451 & $300-450$ \\
\hline Smew & Mergellus albellus & 233 & 139 & $140-230$ \\
\hline Red-breasted Merganser & Mergus serrator & o & o & $\mathrm{O}$ \\
\hline Goosander & Mergus merganser & 70 & 73 & $70-75$ \\
\hline White-headed Duck & Oxyura leucocephala & 213 & 302 & $210-300$ \\
\hline Demoiselle Crane & Anthropoides virgo & 519 & 556 & $520-560$ \\
\hline Common Crane & Grus grus & 125 & 136 & $130-140$ \\
\hline Eurasian Coot & Fulica atra & 1,161 & 1,366 & $1,200-1,400$ \\
\hline
\end{tabular}

Est., estimate.

birds may traditionally use the wetland complex as a stopover site. During the spring migration of many waterfowl, however, the lakes in the region are still covered with ice. At about the same time as the ice melts the extensive floodplains in Western Siberia offer vast areas of suitable habitat. Thus it may be advantageous to skip or to shorten the Tengiz stopover in order to fly directly to Western Siberia. Recent waterbird surveys from the Ural delta, a site of comparable 
Table 2. Estimates of waterbird numbers in the Tengiz-Korgalzhyn region during summer to autumn (end June to November) and status of local breeding. For details on calculations see Calculation of Local Population Sizes.

\begin{tabular}{|c|c|c|c|c|}
\hline Species & $\begin{array}{l}\text { Breeding } \\
\text { status }\end{array}$ & $\begin{array}{l}\text { Est. I } \\
\max \left(N_{j k}\right)\end{array}$ & $\begin{array}{l}\text { Est. } 2 \\
\max \left(N_{k}\right)\end{array}$ & $\begin{array}{l}\text { Total } \\
\text { estimate }\end{array}$ \\
\hline Black-throated Diver & Rare & 15 & 19 & $15-20$ \\
\hline Red-necked Grebe & Common & 665 & 765 & $670-770$ \\
\hline Great Crested Grebe & Common & 10,983 & 13,713 & $11,000-14,000$ \\
\hline Slavonian Grebe & Uncommon & 243 & 304 & $240-300$ \\
\hline Black-necked Grebe & Common & 1,797 & 3,615 & $1,800-3,600$ \\
\hline Dalmatian Pelican & Uncommon & 3,097 & 4,809 & $3,100-4,800$ \\
\hline Great Cormorant & Common & 10,500 & 19,718 & $11,000-20,000$ \\
\hline Grey Heron & Common & 646 & 789 & $650-790$ \\
\hline Great White Egret & Common & 1,222 & 1,531 & $1,200-1,500$ \\
\hline Eurasian Spoonbill & Irregular & 29 & 29 & 30 \\
\hline Greater Flamingo & Common & 22,705 & 22,777 & 23,000 \\
\hline Mute Swan & Common & 4,568 & 4,174 & $4,200-4,600$ \\
\hline Whooper Swan & Common & 3,650 & 4,107 & $3,700-4,100$ \\
\hline Bewick's Swan & - & 12 & 15 & $10-15$ \\
\hline Bean Goose & - & 21 & 21 & 20 \\
\hline Greater White-fronted Goose & - & 426,380 & 458,976 & $426,000-459,000$ \\
\hline Lesser White-fronted Goose & - & 36 & 38 & $35-40$ \\
\hline Greylag Goose & Common & 43,920 & 49,466 & $44,000-49,000$ \\
\hline Red-breasted Goose & - & 649 & 873 & $650-870$ \\
\hline Ruddy Shelduck & - & 36,523 & 22,832 & $23,000-37,000$ \\
\hline Common Shelduck & Common & 48,622 & 44,541 & $45,000-49,000$ \\
\hline Eurasian Wigeon & - & 50,150 & 62,031 & $50,000-62,000$ \\
\hline Gadwall & Common & 66,134 & 90,776 & $66,000-91,000$ \\
\hline Common Teal & - & 20,121 & 30,608 & $20,000-31,000$ \\
\hline Mallard & Common & 38,915 & 67,643 & $39,000-68,000$ \\
\hline Northern Pintail & Common & 31,898 & 48,022 & $32,000-48,000$ \\
\hline Garganey & Common & 10,542 & 9,665 & $9,700-10,500$ \\
\hline Northern Shoveler & Common & 57,020 & 79,964 & $57,000-80,000$ \\
\hline Red-crested Pochard & Common & 32,500 & 22,211 & $22,000-33,000$ \\
\hline Common Pochard & Common & 177,542 & 289,592 & $178,000-290,000$ \\
\hline Ferruginous Duck & Rare & 342 & 345 & $340-350$ \\
\hline Tufted Duck & Uncommon & 15,000 & 15,275 & 15,000 \\
\hline Greater Scaup & - & 2 & 2 & $0-5$ \\
\hline Long-tailed Duck & - & 50 & 53 & $50-55$ \\
\hline Velvet Scoter & - & 2 & 2 & $0-5$ \\
\hline Common Goldeneye & - & 54,600 & 33,508 & $34,000-55,000$ \\
\hline Smew & - & 19,800 & 15,150 & $15,000-20,000$ \\
\hline Red-breasted Merganser & - & 2 & 2 & $0-5$ \\
\hline Goosander & - & 800 & 920 & $800-920$ \\
\hline White-headed Duck & Uncommon & 3,464 & 3,787 & $3,500-3,800$ \\
\hline Demoiselle Crane & Common & 9,514 & 8,967 & $9,000-9,500$ \\
\hline Common Crane & Uncommon & 3,812 & 4,030 & $3,800-4,000$ \\
\hline Eurasian Coot & Common & 181,430 & 245,949 & $181,000-246,000$ \\
\hline
\end{tabular}

Est., estimate.

importance to migrating waterfowl at the northern Caspian Sea, revealed a phenological pattern opposite to the situation at our study area: spring totals exceeded autumn numbers severalfold (V. V. Khrokov, 2005, pers. comm.). This indicates that the large differences in spring and autumn numbers may be caused by loop migration. 
Table 3. Comparison of the estimated peak staging populations of waterbirds in the Tengiz-Korgalzhyn region with flyway population estimates from Wetlands International (2006).

\begin{tabular}{|c|c|c|c|c|c|c|c|}
\hline \multirow[t]{2}{*}{ Species } & \multirow{2}{*}{$\begin{array}{l}\text { IUCN } \\
\text { status }\end{array}$} & \multicolumn{3}{|l|}{ Flyway population } & \multirow{2}{*}{$\frac{\text { Tengiz population }}{\text { estimate }}$} & \multicolumn{2}{|c|}{ Significance (\%) } \\
\hline & & estimate & population & $\begin{array}{l}1 \% \\
\text { criterion }\end{array}$ & & $\overline{\text { Spring }}$ & Autumn \\
\hline $\begin{array}{l}\text { Greater White- } \\
\text { fronted Goose }\end{array}$ & & $375,000-755,000$ & $2,3,4$ & 5,700 & $426,000-459,000$ & $<_{1}$ & 78 \\
\hline Smew & & 30,000 & 3 & 300 & $15,000-20,000$ & 1 & 58 \\
\hline $\begin{array}{l}\text { Dalmatian } \\
\text { Pelican }\end{array}$ & VU & $6,000-9,000$ & 2 & 75 & $3,100-4,800$ & 8 & 53 \\
\hline $\begin{array}{l}\text { White-headed } \\
\text { Duck }\end{array}$ & EN & $5,050-10,050$ & 3,4 & 76 & $3,500-3,800$ & 3 & 48 \\
\hline $\begin{array}{l}\text { Great Crested } \\
\text { Grebe }\end{array}$ & & $20,000-35,000$ & 3,4 & 350 & $11,000-14,000$ & 3 & 45 \\
\hline Common Pochard & & $550,000-850,000$ & 3,4 & 7,000 & $178,000-290,000$ & 2 & 33 \\
\hline Common Shelduck & & $105,000-180,000$ & 3,4 & 1,800 & $45,000-49,000$ & 1 & 33 \\
\hline Ruddy Shelduck & & 100,000 & 4,5 & 1,000 & $23,000-37,000$ & $<_{1}$ & 30 \\
\hline Whooper Swan & & 20,000 & 4 & 200 & $3,700-4,100$ & 4 & 20 \\
\hline Gadwall & & 430,000 & 3,4 & 4,300 & $66,000-91,000$ & $<_{1}$ & 18 \\
\hline Greylag Goose & & 275,000 & 6,7 & 2,750 & $44,000-49,000$ & $<_{1}$ & 17 \\
\hline $\begin{array}{l}\text { Black-necked } \\
\text { Grebe }\end{array}$ & & 25,000 & 3 & 250 & $1,800-3,600$ & 3 & 11 \\
\hline Eurasian Wigeon & & 550,000 & 3,4 & 5,500 & $50,000-62,000$ & $<_{1}$ & 10 \\
\hline Greater Flamingo & & 240,000 & 5 & 2,400 & 23,000 & 4 & 10 \\
\hline Demoiselle Crane & & 100,000 & 5 & $1, \mathrm{OOO}$ & $9,000-9,500$ & 1 & 9 \\
\hline Great Cormorant & & $125,000-225,000$ & 6,7 & 2,000 & $11,000-20,000$ & 3 & 9 \\
\hline $\begin{array}{l}\text { Common } \\
\text { Goldeneye }\end{array}$ & & $100,000-1,000,000$ & 4 & 10,000 & $34,000-55,000$ & $<_{1}$ & 8 \\
\hline $\begin{array}{l}\text { Red-crested } \\
\text { Pochard }\end{array}$ & & 350,000 & 3,4 & 350 & $22,000-33,000$ & 1 & 8 \\
\hline Mallard & & 875,000 & 4,5 & 8,750 & $39,000-68,000$ & $<_{1}$ & 6 \\
\hline Eurasian Coot & & $3,500,000$ & 3,4 & 20,000 & $181,000-246,000$ & $<_{1}$ & 6 \\
\hline Goosander & & 20,000 & 6 & 200 & $800-920$ & $<_{1}$ & 4 \\
\hline Northern Shoveler & & $1,350,000-1,850,000$ & $2,3,4$ & 16,000 & $57,000-80,000$ & $<_{1}$ & 4 \\
\hline Common Crane & & 100,000 & 5 & 1,000 & $3,800-4,000$ & $<_{1}$ & 4 \\
\hline Northern Pintail & & $700,000-1,700,000$ & 3,4 & 7,000 & $32,000-48,000$ & $<_{1}$ & 3 \\
\hline Red-necked Grebe & & 25,000 & 3,4 & 250 & $670-770$ & 3 & 3 \\
\hline Tufted Duck & & $500,000-700,000$ & 3,4 & 6,000 & 15,000 & $<_{1}$ & 3 \\
\hline Great White Egret & & $25,000-100,000$ & 2 & 1,000 & $1,200-1,500$ & $<_{1}$ & 2 \\
\hline Garganey & & $450,000-550,000$ & 2,3 & 5,500 & $9,700-10,500$ & $<_{1}$ & 2 \\
\hline $\begin{array}{l}\text { Red-breasted } \\
\text { Goose }\end{array}$ & VU & 38,500 & 1 & 385 & $650-870$ & $<_{1}$ & 2 \\
\hline Mute Swan & & $260,000-275,000$ & 6 & 2,750 & $4,200-4,600$ & $<_{1}$ & 2 \\
\hline Slavonian Grebe & & $10,000-25,000$ & 3 & 250 & $240-300$ & $<_{1}$ & 2 \\
\hline Common Teal & & $1,900,000$ & 3,4 & 19,000 & $20,000-31,000$ & $<_{1}$ & 1 \\
\hline Bewick's Swan & & 1,000 & 4 & 10 & $10-15$ & $<_{1}$ & 1 \\
\hline Bean Goose & & 5,000 & 2 & 50 & $20-20$ & $<_{1}$ & $<_{1}$ \\
\hline $\begin{array}{l}\text { Lesser White- } \\
\text { fronted Goose }\end{array}$ & VU & $8,000-13,000$ & 1 & 110 & $35-40$ & $<_{1}$ & $<_{1}$ \\
\hline $\begin{array}{l}\text { Ferruginous } \\
\text { Duck }\end{array}$ & NT & $125,000-200,000$ & 3,4 & 2,000 & $340-350$ & $<_{1}$ & $<_{1}$ \\
\hline Velvet Scoter & & 1,500 & 2 & 15 & $0-5$ & $<_{1}$ & $<_{1}$ \\
\hline Grey Heron & & $25,000-1,000,000$ & 4 & 20,000 & $650-790$ & $<_{1}$ & $<_{1}$ \\
\hline Eurasian Spoonbill & & $25,000-100,000$ & 5 & 1,000 & 30 & $<_{1}$ & $<_{1}$ \\
\hline
\end{tabular}


Table 3. Continued.

\begin{tabular}{|c|c|c|c|c|c|c|c|}
\hline \multirow[t]{2}{*}{ Species } & \multirow{2}{*}{$\begin{array}{l}\text { IUCN } \\
\text { status }\end{array}$} & \multicolumn{3}{|l|}{ Flyway population } & Tengiz population & \multicolumn{2}{|c|}{ Significance (\%) } \\
\hline & & estimate & population & $\begin{array}{l}1 \% \\
\text { criterion }\end{array}$ & estimate & Spring & $\overline{\text { Autumn }}$ \\
\hline Red-breasted & & 10,000 & 3 & 100 & $0-5$ & $<_{1}$ & $<_{1}$ \\
\hline $\begin{array}{l}\text { Black-throated } \\
\text { Diver }\end{array}$ & & $250,000-500,000$ & 1,2 & 3,750 & $15-20$ & $<_{1}$ & $<_{1}$ \\
\hline Greater Scaup & & $100,000-200,000$ & 2 & 1,500 & $\mathrm{o}-5$ & $<_{1}$ & $<_{1}$ \\
\hline Long-tailed Duck & & $4,600,000$ & 2 & 20,000 & $50-55$ & $<_{1}$ & $<_{1}$ \\
\hline
\end{tabular}

The numbers in the "Population" column refer to the sequence of populations (sequential numbering of rows) for the respective species as given in Wetlands International (2006). The significance level for the Tengiz region was calculated from the mid-range values and is given as percentages of the flyway population. NT, Near Threatened; VU, Vulnerable; EN, Endangered.

Among the species exceeding $40 \%$ of the estimated flyway population two are classified as globally threatened: the White-headed Duck, which is Endangered, and the Dalmatian Pelican, which is Vulnerable. In the study area, White-headed Ducks gathered in large flocks in late summer and early autumn, with numbers peaking in September (Schielzeth et al. 2003). The number of local breeding pairs is unknown, and it is likely that breeding birds from northern Kazakhstan and southern Western Siberia migrate to the Tengiz-Korgalzhyn region for moulting. The total Tengiz-Korgalzhyn population in late summer was estimated at 4,000-5,000 birds for the period 1999-2002 (Schielzeth et al. 2003). The slightly larger data set analysed here indicates that numbers might be on the lower limit of this estimate. The Dalmatian Pelican is a breeding bird in the reeds of Lake Korgalzhyn (c. 500-1,000 pairs). Larger flocks occurred at sites both within and outside the zapovednik (see Appendix in Supplementary materials). Outside the zapovednik the freshwater lakes east of Korgalzhyn village (Uyalinskij lake system; sites 49, 57, 59 and 65 in Figure 5) as well as Lake Sholak (sites 24, 50) were of particularly high importance. These lakes are used for hunting and fishing and are managed by hunting associations (see below), but we could not detect any direct harm to pelicans.

The species with the highest share of the relevant flyway population was the Greater Whitefronted Goose Anser albifrons (GWFG). The importance of the region for migrating arctic geese has been known for a long time (Vinogradov 1990). Many GWFG of subsp. albifrons migrate from their breeding grounds in arctic Western Siberia via Central Kazakhstan and the Caspian Sea further to South-eastern and Central Europe (Michev and Profirov 2003, Mooij et al. 1999, Veen et al. 2005). On spring migration, however, far fewer arctic geese migrate via Central Kazakhstan, which explains their low numbers in the Tengiz-Korgalzhyn region at this time. Among the GWFG there were regularly groups of Lesser White-fronted Goose Anser erythropus (LWFG) and Red-breasted Goose Branta ruficollis (RBG), two species that are considered Vulnerable at the global scale. Since we did not use any extrapolations (i.e. projecting the ratio of LWFG/GWFG and RBG/GWFG from subsamples to the total of arctic geese present), our method certainly underestimates the true numbers of these species. By random sampling from a total of $c .500,700$ geese present in the TengizKorgalzhyn region in early October 1999 Tolvanen et al. (2000) extrapolated numbers for four species of geese. This approach is quite different from the one we present in this paper, but is more efficient for obtaining a reasonable estimate of rarer species. Tolvanen et al. (2000) estimated the numbers of LWFG and RBG at 940 and 8,300 individuals, respectively. These figures would increase the share of the flyway population passing the study area to $9 \%$ and $22 \%$, respectively. Further counts, including systematic sub-sampling, would help to clarify the importance of the study area for LWFG and RBG.

The general status of protection is favourable in the Tengiz-Korgalzhyn region. The core part of the region enjoys protection as it belongs to a strict nature reserve where rangers control 


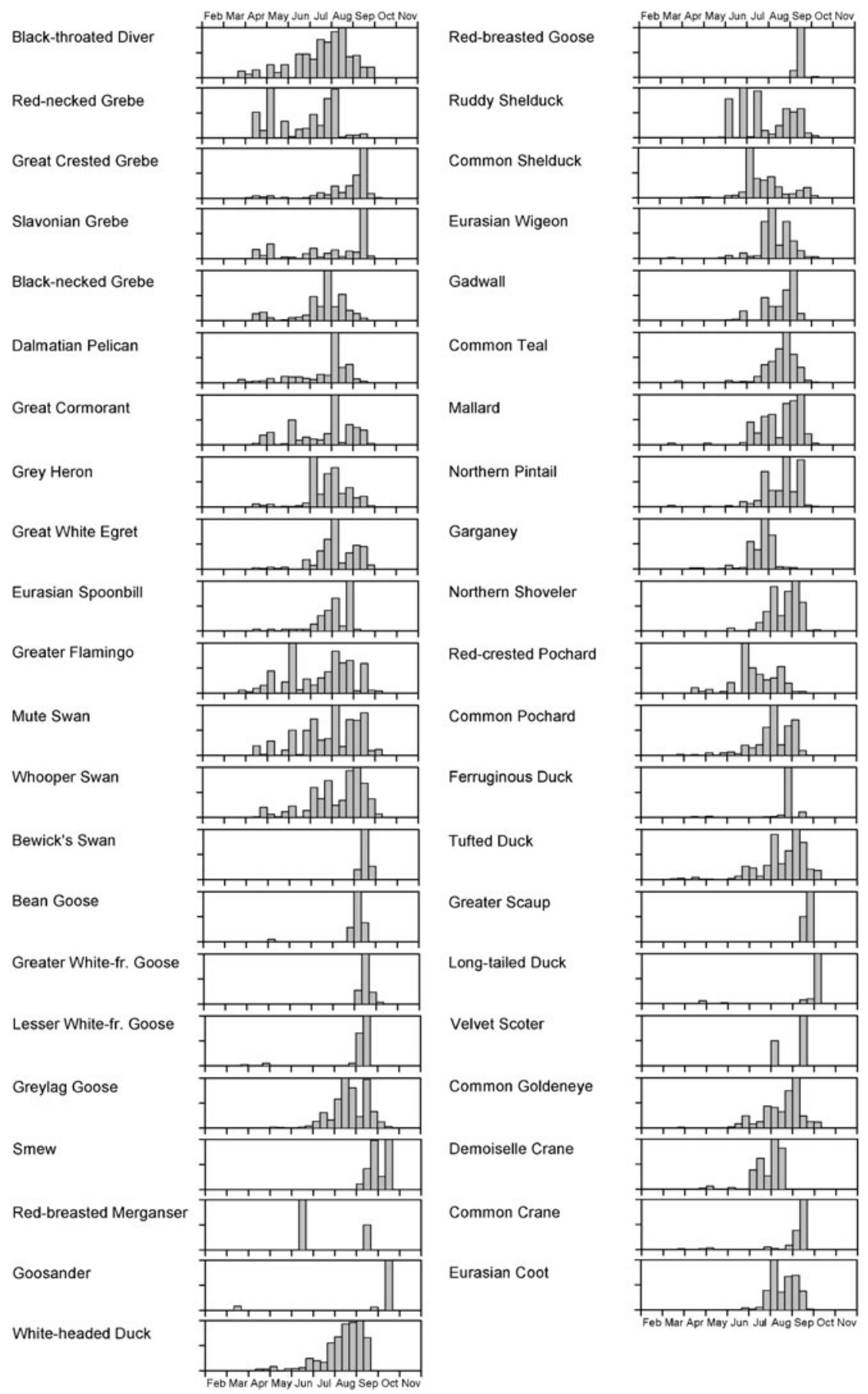

Figure 4. Phenology of waterbirds in the Tengiz-Korgalzhyn region. For each species the value $N_{k}$ for any third of a month $k$ is given relative to the third of a month with the highest value $\max \left(N_{k}\right)\left(=E_{s t}\right)$, i.e. for each species the maximum is $100 \%$. For details on calculations of $N_{k}$ see the section Calculation of Local Population Sizes. 


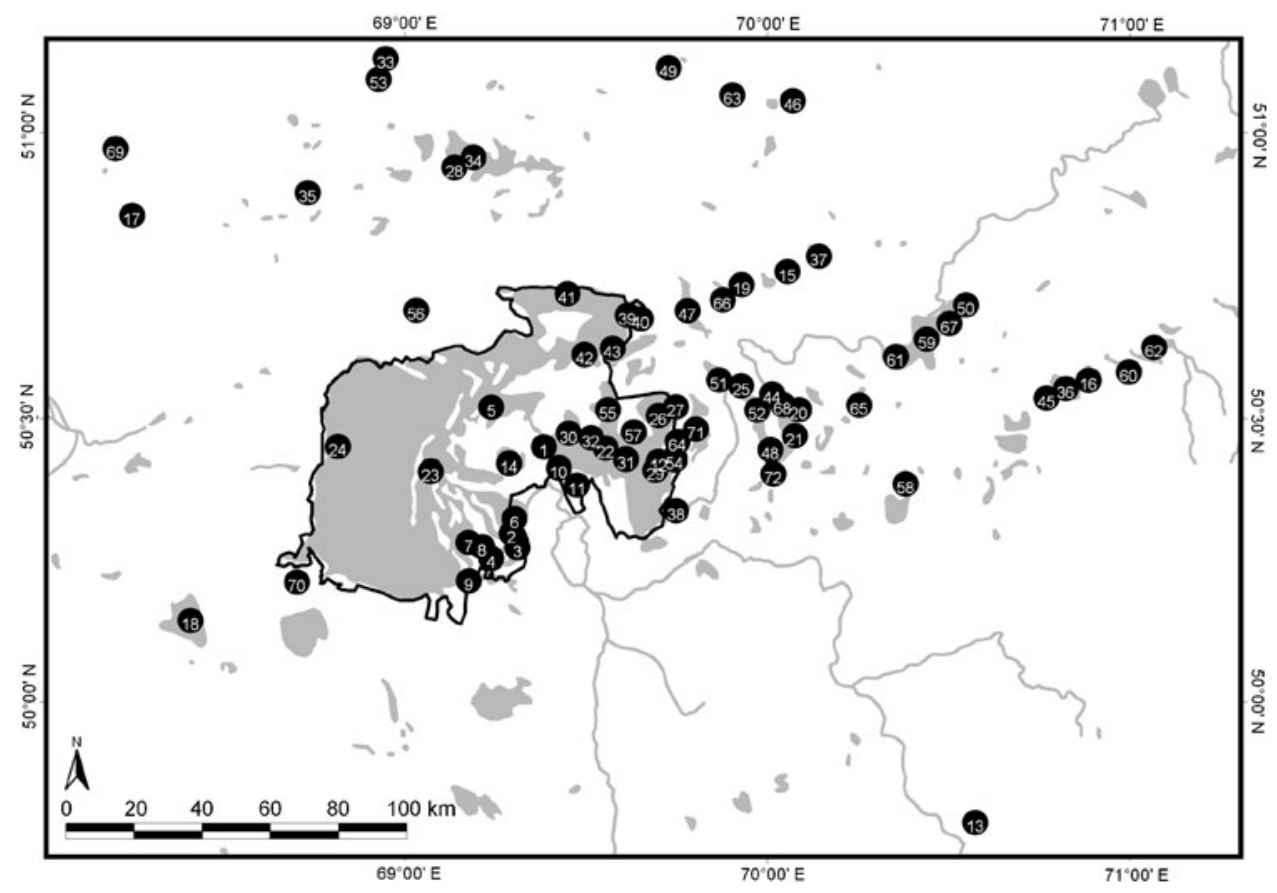

Figure 5. Individual sites that held more than 20,000 waterbirds or more than $1 \%$ of the flyway population for a particular species at least once in 1999-2004 (flyway population sizes based on Wetlands International (2006); see Table 3). The black line shows the borders of the zapovednik. The numbering refers to the sequence of sites in the Appendix (Supplementary materials).

poaching and illegal fishing. Most of the important sites outside the zapovednik allow hunting activity during the hunting season (first weekend of September to 15 December). There is self-supply hunting by locals at many places, but many of the larger lakes (in particular those holding roosts of geese) are managed by hunting associations. This means that hunting is limited to people paying hunting fees, and at most places wardens are present to limit poaching. We assume that the hunting bags do little harm to the numerous GWFG. The problem is, however, that the threatened (and protected) species LWFG and RBG are bagged too, when mistaken for GWFG. A detailed analysis of hunting bags could give valuable insight in the relevance of this issue.

Besides hunting, fishing is popular at many lakes outside the zapovednik. Fishing is not limited to any particular season. In particular gillnets pose a threat for diving waterbirds (e.g. Schielzeth et al. 2003), but other than anecdotal evidence there are currently no data on how serious this issue might be. Electric powerlines form a hazard for waterfowl when located close to lake shores. At particularly vulnerable places larger numbers of casualties have been found (e.g. 106 individuals of 11 species of Anseriformes along $10 \mathrm{~km}$ of powerline on 29 September 1999, unpubl. data). While there are hardly any powerlines within the zapovednik, there is a multitude of them in the eastern part of the region. Conservation action should focus first on those in the close vicinity of lakes.

Large numbers of geese, cranes and some duck species (mainly Northern Pintail Anas acuta and Mallard Anas platyrhynchos) feed on agricultural fields. Due to economic changes and the barely sustainable agriculture in the dry steppes of the Tengiz-Korgalzhyn region, many fields have fallen fallow in recent decades (Dieterich 2000). If this trend continues, it may affect the numbers of these species. The most serious hazard for the region, however, is increasing extraction of fresh water at growing cities upstream (e.g. the capital Astana), since isolated 
steppe lakes are highly dependent on stable water inflow. Although there is currently no immediate threat, any change in water supply should be monitored carefully.

\section{Acknowledgements}

We are grateful to Axel Bräunlich, Andreas J. Helbig, Dorit Liebers, Thomas Noah and Jörg Ratayczak for providing data and to Timur Iskakov, Tonya Grishina, Olga Koshkina and Gennadij Sidorin for their substantial logistical help. Furthermore, we thank Simon Delany, Richard Hearn, Wiltraud Engländer, Johannes Wahl and an anonymous referee for helpful comments on earlier drafts of the paper. Surveys in 1999, 2000, 2002 and 2004 were kindly funded by the ASA Program (administered by InWEnt), Naturschutzbund Deutschland (NABU) and the Royal Society for the Protection of Birds (RSPB).

Supplementary material for this article can be found at journals.cambridge.org.

\section{References}

Andrusenko, N. N. (2002) Dopolneniya k spisku ptits Kurgaldzhinskogo zapovednika [Addition to the bird list of the Kurgaldzhinskij zapovednik]. Selevinia 10: 122-126. (In Russian.)

Andrusenko, N. N. (2004a) Ekologicheskie aspekty linki i rezultaty koltsevaniya lebedei v Akmolinskoj oblasti (Kazakhstan) [Ecological aspects of moult and results of Swan ringing in the Akmola region (Kazakhstan)]. Pp. 40-62 in A. E. Gavrilov, ed. Migratsii ptits $v$ Azii [Migration of birds in Asia]. Alma-Ata: Nauka. (In Russian.)

Andrusenko, N. N. (2004b) O zaletakh Flamingi (Phoenicopterus roseus Pall.) [About Flamingo (Phoenicopterus roseus Pall.) migration]. Pp. $63-73$ in A. E. Gavrilov, ed. Migratsii ptits v Azii [Migration of birds in Asia]. Alma-Ata: Nauka. (In Russian.)

Beintema, A. and van Vessem, J., eds. (1999) Strategies for conserving migratory waterbirds. Proceedings of Workshop 2 of the 2nd International Conference on Wetlands and Development held in Dakar, Senegal, 8-14 November 1998. Wageningen: Wetlands International. Wetlands International Publication No. 55.

Bianki, V. V. and Dobrynina, I. N., eds. (1997) Migratsii ptits vostochnoj Evropy i Severnoj Azii - Plastinchatik lyuvye - rechnye utki [Migration of birds in Eastern Europe and Northern Asia - Anseriformes - dabbling ducks]. Moscow: Nauka. (In Russian.)
Bibby, C., Jones, M. and Marsden, S. (1998) Expedition field techniques: bird surveys. London: Birdlife International/Royal Geographic Society.

BirdLife International (2007) Kazakhstan signs up to protect important wetlands. http:// www.birdlife.org/news/news/2007/o1/ kazakhstan_ramsar.html, accessed February 2007.

Davis, T. J. (1994) The Ramsar Convention manual: a guide to the Convention on Wetlands of International Importance. Gland, Switzerland: Ramsar Convention Bureau.

de Beurs, K. M. and Henebry, G. M. (2004) Land surface phenology, climatic variation, and institutional change: analyzing agricultural land cover change in Kazakhstan. Remote Sens. Environ. 89: 497-509.

Delany, S., Reyes, C., Hubert, E., Pihl, S., Rees, E., Haanstra, L. and van Strien, A. (1999) Results from the International Waterbird Census in the Western Palearctic and Southwest Asia, 1995 and 1996. Wageningen: Wetlands International. Wetlands International Global Series No. I1.

Dieterich, T. (2000) Landschaftsökologische Untersuchungen an Ackerbrachen im zukünftigen Biosphärenreservat "Tengis See" in Zentralkasachstan und ihr Regenerierungsvermögen zur Steppe. Diploma thesis, Ernst Moritz Arndt University, Greifswald, Germany. (In German.)

Eichhorn, G. and Khrokov, V. V. (2002) Decline in breeding Sociable Plovers Chettusia gregaria in the steppes of 
Naurzum and Korgalzhyn, Kazakhstan. Sandgrouse 24: 22-27.

Fokin, S., Kuzyakin, V., Kalchreuter, H. and Kirby, J. S. (2000) The Garganey in the former USSR. A compilation of the life-history information. Wageningen, Wetlands International. Wetlands International Global Series No. 7.

Frazier, S. (1999) Ramsar sites overview: a synopsis of the world's wetlands of international importance. Wageningen: Wetlands International.

Frederick, P. C., Hylton, B., Heath, J. A. and Ruane, M. (2003) Accuracy and variation in estimates of large numbers of birds by individual observers using an aerial survey simulator. J. Field Ornithol. 74: 281-287.

Frederiksen, M., Fox, A. D., Madsen, J. and Colhoun, K. (2001) Estimating the total number of birds using a staging site. $J$. Wildl. Manage. 65: 282-289.

Gilissen, N., Haanstra, L., Delany, S., Boere, G. and Hagemeijer, W. (2002) Numbers and distribution of wintering waterbirds in the Western Palearctic and Southwest Asia in 1997, 1998 and 1999. Results from the International Waterbird Census. Wageningen: Wetlands International. Wetlands International Global Series No. 11 . Hagemeijer, W. J. M. and Blair, M. J. (1997) The EBCC atlas of European breeding birds. Their distribution and abundance. London: T. \& A. D. Poyser.

Koshkin, A. V. (2002) Dopolneniya k faune ptits Kurgaldzhinskogo zapovednika [Addition to the bird fauna of the Kurgaldzhinskii zapovednik]. Selevinia 10: 127-130. (In Russian.)

Koshkin, A. V. (2003) Ornithologicheskie nablyudeniya v Kurgaldzhinskom zapovednike v 2003 g. [Ornithological observations from the Kurgaldzhinskij zapovednik in 2003]. Kazakhstanskij ornitologicheskij Byulleten 2: 54-56. (In Russian.)

Koshkin, A. V. and Koshkina, O. I. (2003) Kratkij obzor sostoyaniya krasnoknizhnykh vidov ptits v Tengizkom regione (Tsentralnyj Kazakhstan) [Short review of the status of Red Data Book bird species in the Tengiz region (Central Kazakhstan)]. Selevinia 11: 209-210. (In Russian.)
Koshkina, O. I. (1999) Survey of goose populations in the Kurgaldzhinskij State Nature Reserve in Central Kazakhstan. Casarca 5: 331-336. (In Russian.)

Krivitskij, I. A., Khrokov, V. V., Volkov, E. N. and Zhulij, V. A. (1985) Ptitsy Kurgaldzhinskogo zapovenika [Birds of the Kurgaldzhinskij zapovednik]. AlmaAta: Nauka. (In Russian.)

Michev, T. and Profirov, L. (2003) Midwinter numbers of waterbirds in Bulgaria (19772001). Sofia: Pensoft Publishers.

Mooij, J. H., Farago, S. and Kirby, J. S. (1999) White-fronted Goose Anser albifrons albifrons. Pp. $94-128$ in J. Madsen, G. Cracknell and A. D. Fox, eds. Goose populations of the Western Palearctic. A review of status and distribution. Wageningen: Wetlands International.

Pradel, R., Rioux, N., Tamisier, A. and Lebreton, J.-D. (1997) Individual turnover among wintering Teal in Camargue: a mark-recapture study. J. Wildl. Manage. 61: 816-821.

Rappoldt, C., Kersten, M. and Smit, C. (1985) Errors in large-scale shorebird counts. Ardea 73: 13-24.

Rose, P. M. (1995) Western Palearctic and South-west Asia waterfowl census 1994. Slimbridge, U.K.: International Waterfowl and Wetlands Research Bureau. IWRB Publication 35.

Schaub, M., Pradel, R., Jenni, L. and Lebreton, J. D. (2001) Migrating birds stop over longer than usually thought: an improved capturerecapture analysis. Ecology 82: 852-859.

Schielzeth, H., Lachmann, L., Eichhorn, G. and Heinicke, T. (2003) The White-headed Duck Oxyura leucocephala in the TengizKorgalzhyn region, Central Kazakhstan. Wildfowl 54: 115-129.

Scott, D. A. and Rose, P. M. (1996) Atlas of Anatidae populations in Africa and Western Eurasia. Wageningen: Wetlands International. Wetlands International Publication No. 41.

Sema, A. M. (2002) Distribution of Kazakhstan birds over wintering grounds from ring-recovery data. Pp. 171-186 in I. N. Dobrynina, ed. Bird ringing and marking in Russia and adjacent countries 19881999. Moscow. (In Russian.) 
Sklyarenko, S. L. (2006) Issledovaniya po klyuchevym ornitologicheskim territoriyam v Kazakhstane i Srednej Azii [Research on Important Bird Areas in Kazakhstan and Central Asia]. Almaty: Association for the Conservation of Biodiversity in Kazakhstan (ACBK). (In Russian.)

Solokha, A. (2006) Results from the international waterbird census in Central Asia and the Caucasus 2003-2005. Moscow: Wetlands International.

Tolvanen, P., Eskelin, T., Aarvak, T., Eichhorn, G., Øien, I. J. and Gurtovaya, E. (2000) Monitoring the autumn staging of Lesser White-fronted Geese in Kazakhstan, October 1999. Pp. 43-67 in P. Tolvanen, I. J. Øien and K. Ruokolainen, eds. Fennoscandian Lesser White-fronted Goose conservation project. Annual report 1999. Helsinki: WWF Finland Report 12 and NOF Rapportserie Report no. I.

Underhill, L. G. and Prŷs-Jones, R. P. (1994) Index numbers for waterbird populations.
I. Review and methodology. J. Appl. Ecol. 31: $463-480$.

Veen, J., Yurlov, A. K., Delany, S. N., Mikhantiev, A. I., Selivanova, M. A. and Boere, G. C. (2005) An atlas of movements of Southwest Siberian waterbirds. Wageningen: Wetlands International.

Viksne, J. A., ed. (1989) Migratsii ptits Vostochnoj Evropy i Severnoj Azii - Plastinchatoklyuoye [Migration of birds in eastern Europe and northern Asia - Anseriformes]. Moscow, Nauka. (In Russian.)

Vinogradov, V. G. (1990) Anser erythropus in the USSR Pp. 199-203 in G. V. T. Matthew, ed. Managing waterfowl populations. Proceedings of the IWRB Symposium Astrakhan 1989. Slimbridge, U.K.: IWRB. Special Publication No. 12.

Wetlands International (2006) Waterbird population estimates. Fourth edition. Wageningen: Wetlands International. Wetlands International Global Series No. 12.

\section{HOLGER SCHIELZETH*}

Max Planck Institute for Ornithology, P. O. Box 1564, 82305 Starnberg (Seewiesen), Germany.

\section{GÖTZ EICHHORN}

Animal Ecology, Centre for Ecological and Evolutionary Studies, University of Groningen, P. O. Box 14, 9750 AA Haren, The Netherlands.

\section{THOMAS HEINICKE}

Chausseestr. 1, 18581 Vilmnitz, Germany.

\section{JOHANNES KAMP}

Hindenburgstr. 3, 26122 Oldenburg, Germany.

\section{MAXIM A. KOSHKIN}

Association for the Conservation of Biodiversity in Kazakhstan (ACBK), Off. 520, ul. Seifullina 597, Almaty 480072, Republic of Kazakhstan.

\section{ALEXEJ V. KOSHKIN}

Korgalzhynskij zapovednik, ul. M. Rakhimzhana 20, p. Korgalzhyn 474210, Republic of Kazakhstan.

\section{LARS LACHMANN}

Royal Society for the Protection of Birds (RSPB), European Programmes Dept., The Lodge, Sandy, Bedfordshire, SG19 2DL, U.K.

*Author for correspondence; email: schielz@orn.mpg.de 